\title{
Waste Municipal Service and Informal Recycling Sector in Fast-Growing Asian Cities: Co-Existence, Opposition or Integration?
}

\author{
Rémi de Bercegol ${ }^{1, *}$, Jérémie Cavé ${ }^{2}$ and Arch Nguyen Thai Huyen ${ }^{3}$ \\ 1 Centre National de la Recherche Scientifique, UMR 8586 PRODIG, 2 Rue Valette, 75005 Paris, France \\ 22 Ter Rue des Puits Creuses, 31000 Toulouse, France; urbanalyse@gmail.com \\ 3 Faculty of Urban and Rural Planning, Hanoi Architectural University, Km10 Nguyen Trai, Thanh Xuan, \\ Hanoi 100803, Vietnam; thaihuyennguyen@gmail.com \\ * Correspondence: remi.debercegol@cnrs.fr
}

Received: 24 October 2017; Accepted: 6 December 2017; Published: 11 December 2017

\begin{abstract}
Despite being generally poorly recognized by public authorities, informal recycling remains nevertheless a major component in the waste sector, which questions the legitimacy of the official waste arrangements. A look at the current transformation in Hanoi (Vietnam), Delhi (India) and Surabaya (Indonesia) allows us to understand the socio-technical aspects of infrastructural choices in the management of waste generated in fast-growing Asian cities. The three cases present similar traditional recycling practices yet contrasted (non-) regulation within their waste policies. From the co-existence of a municipal waste management service with a traditional informal recycling sector, to an opposition between both, there is also a possibility of making use of the existing local practices to achieve a more sustainable system.
\end{abstract}

Keywords: waste management; linear system; recycling; informal sector; Hanoi; Surabaya; Delhi

\section{Introduction}

Waste systems are a highly pertinent "site" of observation for an understanding of the challenges that fast-growing Asian cities have to face, both from a socio-economic and environmental perspective, and their potential responses to it. These agglomerations are spreading at a scale never seen before, creating huge metropolises and a continuum of smaller towns in less-urbanized regions. In 2014, 53\% of the world' urban population was already located in Asia [1], and this share will increase again by 2050, with more and more inhabitants slowly adopting middle class consumption patterns. Of course, this rapid urbanization has contributed to the socio-economic development of countries but it also has come with counter effects, socio-economically, with an estimated 880 million population of slum dwellers in 2014 [2], as well as environmentally with an increase of solid waste generated in cities (See Table 1).

Table 1. Urban Solid waste-Generation rate (selected Asian countries).

\begin{tabular}{ccccc}
\hline \multirow{2}{*}{ Country } & \multicolumn{2}{c}{$\mathbf{1 9 9 5}$} & \multicolumn{2}{c}{ Projections for 2025 } \\
\cline { 2 - 5 } & $\begin{array}{c}\text { Urban Population } \\
\mathbf{( 1 0 0 0} \mathbf{s})\end{array}$ & $\begin{array}{c}\text { Urban Generation Rate } \\
\text { (Kg/Per Head/Day) }\end{array}$ & $\begin{array}{c}\text { Urban Population } \\
\mathbf{( 1 0 0 0 ~ s )}\end{array}$ & $\begin{array}{c}\text { Urban Generation Rate } \\
\text { (Kg/Per Head/Day) }\end{array}$ \\
\hline Bangladesh & 27,786 & 0.49 & 72,844 & 0.60 \\
China & 374,257 & 0.79 & 851,430 & 0.90 \\
India & 253,473 & 0.46 & 523,202 & 0.70 \\
Japan & 81,079 & 1.47 & 85,877 & 1.30 \\
Republic of Korea & 34,935 & 1.59 & 42,910 & 1.40 \\
\hline
\end{tabular}


Table 1. Cont.

\begin{tabular}{ccccc}
\hline \multirow{2}{*}{ Country } & \multicolumn{2}{c}{$\mathbf{1 9 9 5}$} & \multicolumn{2}{c}{ Projections for 2025 } \\
\cline { 2 - 5 } & $\begin{array}{c}\text { Urban Population } \\
\mathbf{( 1 0 0 0} \mathbf{~ s )}\end{array}$ & $\begin{array}{c}\text { Urban Generation Rate } \\
\mathbf{( K g / P e r ~ H e a d / D a y ) ~}\end{array}$ & $\begin{array}{c}\text { Urban Population } \\
\mathbf{( 1 0 0 0 ~ s )}\end{array}$ & $\begin{array}{c}\text { Urban Generation Rate } \\
\text { (Kg/Per Head/Day) }\end{array}$ \\
\hline Lao People's & 836 & 0.69 & 4050 & 0.80 \\
Democratic Republic & 11,468 & 0.81 & 27,188 & 1.40 \\
Malaysia & 1289 & 0.60 & 2172 & 0.90 \\
Mongolia & 11,372 & 0.45 & 25,539 & 0.60 \\
Myanmar & 2356 & 0.50 & 10,717 & 0.60 \\
Nepal & 33,786 & 0.52 & 64,951 & 0.80 \\
Philippines & 3480 & 1.10 & 5362 & 1.10 \\
Singapore & 3131 & 0.89 & 3788 & 1.00 \\
Sri Lanka & 18,208 & 1.10 & 30,679 & 1.50 \\
Thailand & 16,202 & 0.55 & 41,371 & 0.70 \\
Vietnam & & & & \\
\hline
\end{tabular}

Source: [3] (p. 177)

As the wastage of resources will no longer be tenable in future, there is a need for considerations for more circularity of flows and materials [4,5]. In this regard, "Asian cities [ ... ] have extensive 'waste economies'" [6] could indicate potential paths of action to deal with the challenge of more sustainable urbanization. Indeed, deeply embedded in culture, reuse and recycling practices are highly dynamic in Asia and, by retrieval of used materials, contribute to reducing the pressure on resources as well as offering a living for many laborers involved in small-scale recycling industries. Nevertheless, these waste economies remain often relegated to informality, which raises the question of their articulation with the municipal system. Taking a socio-technical approach, this article aims at exploring how the recycling sector interplays with the existing waste infrastructures of fast-growing Asian cities. How do these municipalities manage their waste and consider recovery practices? Which role is the informal sector playing in municipal waste systems? What does this articulation reveal about the challenges that are facing fast Asian cities? We make the hypothesis that the relationship between municipal service and recycling informal sector reveals specific political choices in the making of the city, which expresses different ways of dealing with urban socio-environment issues that in fine reflects the transformation of relationships between state and society.

A look at the current situation of waste management in Asian cities reveals the discrepancies of the chosen public strategies, and the existing drivers that could lead to an implementation of more efficient polices in this area. Crossing the perspectives of Hanoi (Vietnam), Delhi (India) and Surabaya (Indonesia), this paper presents different cases of co-existence, integration or opposition between the informal system of recycling and the waste municipal service. These three fast-growing cities are very different in terms of demographic size and area (see Table 2) but are confronted with similar challenges in handling their important quantities of waste.

Table 2. Surabaya, Hanoi, Delhi.

\begin{tabular}{ccccc}
\hline City & $\begin{array}{c}\text { National GDP } \\
\text { (Billion USD) }\end{array}$ & $\begin{array}{c}\text { Population } \\
\text { (Million) }\end{array}$ & Area $\mathbf{( k m}^{\mathbf{2}}$ ) & $\begin{array}{c}\text { Municipal Waste } \\
\text { Collected Per Day }\end{array}$ \\
\hline $\begin{array}{c}\text { Surabaya } \\
\text { Hanoi }\end{array}$ & $862(2016)$ & $3(2016)$ & 375 & 1800 tons \\
Delhi & $194(2015)$ & $7.5(2015)$ & 3229 & 6420 tons \\
\hline
\end{tabular}

Source: compilation of municipal data for each city.

The illustration of Hanoi is issued from the ongoing project "Jeai Recycurbs Viet" funded by the Institut de Recherche pour le Développement. The examples of Surabaya and Delhi were studied within the project "Orva2D" financed by the Agence Française de Développement. In Surabaya, the field work was conducted in close cooperation with the environmental department of the Institut Teknologi Sepuluh Nopember (ITS). Both programs deal specifically with the issue of municipal 
solid waste, which considers essentially household waste, leaving aside industrial waste, which is not handled by municipal bodies. In the three cases, numerous semi-directive interviews have been conducted with agents involved in the formal sector: engineers, politicians and private agencies who showed us the treatment sites. A large part of the fieldwork also included meetings and follow-up with informal and formal agents who are part of the waste recycling chain, from collection to treatment plants (collectors, retrievers, resellers, recyclers).

The three cases present similar traditional recycling practices but contrasted regulation of these within their waste policies. The case of Hanoi illustrates a traditional co-existence of a municipal waste management system with a traditional informal recycling sector, which tends to complement each other, as it is the case in many cities in Asia. The example of Delhi shows that public authorities can deny the importance of the informal sector, by imposing controversial large-scale technologies to handle the municipal waste, without taking into account the existing potentialities of the sector. Finally, the experience of Surabaya demonstrates that under strong political pressure, this recycling sector can be partly recognized and inspire innovative policies to improve its efficiency. We then conclude by pleading for a potential paradigm shift that Asian cities could take towards a more circular model in handling their waste through an integration and upgrading of existing reuse and recycling practices.

\section{Empirical Evidence of Co-Existence, Opposition or Integration of Informal Sector and Municipal Service in Hanoi, Delhi and Surabaya}

\section{1. "Dong Nat" in Hanoi: A Co-Existence of a Traditional Recycling Sector with the Municipal Waste Management System}

With 91.7 million inhabitants in 2015, Vietnam is ranked third among the most populous countries in Southeast Asia after Indonesia and Philippine. Among the top five economies of the Association of Southeast Asian Nations (Indonesia, Malaysia, Philippines, Thailand and Vietnam), Vietnam was leading with GDP growth in 2016 at $6.2 \%$, which is 202.6 billion USD in 2016. The state capital, Hanoi is the country's second largest city by population. Since the expansion of its administrative area in 2008, which has tripled its size, Hanoi counts among the 17 biggest capital in the world. It covers a total 334,470 hectares for 7.5 million of inhabitants in 2015 (against 3.4 million in 2008). Administratively, it includes 30 administrative subdivisions with 12 urban districts, one commune-level town and 17 rural districts.

According to the official statistics from the Ministry of National Resources and Environment [7], the total solid waste in urban areas of Vietnam was estimated around 32,000 tons/day in 2014, with a collection rate estimated at $85 \%$ for urban areas, $60 \%$ for suburban and $40 \%$ in rural areas. In Hanoi, approximately 6420 tons per day is sent to the landfill (with more than 5000 tons from the urban areas of the city). This complete absence of municipal valorization will require new available spaces for landfilling within two years. Officially, the collection and treatment of domestic waste within Hanoi Municipality is delegated to Urban Environment One Member State-owned Limited Company (URENCO) and 17 other private companies chosen by the local authorities. URENCO is responsible for 4 central urban districts of Hanoi, which represents only 10\% of the Hanoi spatial territory.

In reality, this formal system collects mostly organic or unrecoverable components, leftover by a dynamic informal sector, which recovers the most valuable waste (such as plastics, papers, metals) at many points, from the household level, through to dumpsites where 800 waste pickers are informally working [8]. This traditional system feeds on a waste economy, which is also found in many other Asian cities. In practice, most Vietnamese families have the habit of separating recoverable dry waste, in order to sell it to more than 10,000 itinerant waste buyers (called "dong nat", similar to "kabariwalla" of Delhi, cf. following case) walking in the streets daily, buying recyclable materials directly from the inhabitants. In Hanoi, the network of "dong nat" is organized through an old migratory chain originating from the coastal province of Nam Dinh. The collected waste is then sold to wholesalers settled in 800 waste depots (called "bãi") spread all over the city [9]. From there, the waste is then sent 
to recycling units in cluster villages in the periphery of Hanoi. Each of these clusters is specialized in the recycling of one particular material. Some craft villages, specializing in the recycling of paper, plastic and metals, etc., have been expanded significantly, contributing to job creation, and, in turn, raising incomes and reducing poverty. In Hanoi, it is strongly embedded with local practices and complement the formal waste management system, by recycling around $20 \%$ of the waste generated in Hanoi [7], thus diminishing significantly the quantity to be handled by the official delegates in charge of the service. The government, aware of this contribution, tolerates the sector, but without officially integrating it. This lack of proper regulation and norms creates negatives externalities of recycling, notably causing serious environmental pollution due to the use of out-of-date technologies lacking treatment functions.

\subsection{Waste-to-Energy Strategies in Delhi: Neglecting Recycling Sector}

Although it is now a major player on the international stage and has a growth rate that is the envy of most countries in Europe (with a GDP of USD 1670 billion in 2013, +3.2\% in 2014), India is struggling to control the adverse effects that rapid economic development is having on its urban environment. Contributing between $60 \%$ and $65 \%$ to the country's GDP, cities act as a showcase for the country but are literally drowning in their own solid waste. It is estimated that over 125,000 tons of solid waste is produced per day [10] and in Delhi, for instance, the municipal council has to manage no fewer than 9000 to 10,000 tons of waste each day. In addition, this figure does not take into account the informal collection system, which is difficult to quantify for a city of this size, but reduce the quantity to be treated by the municipality. However, India's capital city, home to over 16 million people, suffers from a severe lack of space in which to treat this huge volume of rubbish. Since 1975, around twenty landfills have been closed down and, in 2014, there were only four large landfills still in use, three of which are overloaded and, being well beyond the end of their useful life (ten to twenty years), they now form rubbish mountains several meters high. In this environment, waste incineration technology seems to be a panacea, made all the more appealing by the fact that it also enables energy recovery as burning the waste produces electricity: "Waste-to-Energy is for us an ideal tool to bypass our constraint of space for new landfills and, we hope, to generate at the same time valuable revenue out of waste" (dixit Municipal Executive Engineer, interviewed in January 2016). The government has thus recently appointed private operators to manage three new waste-to-energy facilities in Delhi, with two of them already operational since 2012 and 2017. However, use of this Western-based technology remains controversial: firstly, for environmental reasons as the air pollution it creates is likely to exacerbate the already dire public health situation in Delhi (concentrations of fine particles-2.5 microns or smaller-are already nearly 15 times higher than the WHO guideline levels-[11]; and secondly for technical reasons, as the incoming waste has a low calorific value, which reduces energy recovery levels (mostly biodegradable, some of the most combustible solid waste, such as paper and plastics, is removed before the waste reaches the energy-to-waste facilities).

This incineration strategy, which is being accompanied by the progressive privatization of the entire solid waste collection chain, is in direct competition with waste recycling; an alternative option that is not yet widely recognized in Delhi or in other cities in India. Although the exact number is not known, it is estimated that there are at least 50,000 to 150,000 informal waste pickers making their rounds through the city every day to feed a system of "kabariwalla" which will buy the waste and resell it to a chain of small scale industries of recycling. As each picker collects around forty kilos of solid waste, it is estimated that a minimum of 2000 tons of waste collected on average per day (around 20\% of the waste generated daily in Delhi). They also collect some of the solid waste from the city's industrial areas and sometimes even from neighboring states. Chintan ("Chintan" http:/ / www.chintan-india.org), an non-governmental organisation working to support informal waste pickers in Delhi, estimates that, as well as reducing the amount of waste sent to landfill sites, the informal workers help to reduce emissions by 900,000 tons of $\mathrm{CO}_{2}$ per year [12] by recycling materials free of cost for the public authorities, saving 15 million rupees per day to the 
municipality (307,000 USD/day) if they were getting paid minimum wages [13]. However, without proper public support, the precarious labor conditions of the workers keep deteriorating. This can already be seen in the implementation of the Okhla waste-to-energy plant for the rag-pickers living in its vicinity. Here, workers' earnings have decreased by $21 \%$ according to a survey based on a sample of 109 persons working there [12] (p. 12). As stated by the Alliance of Indian Wastepickers: "informal workers are highly vulnerable, needing special and urgent attention. Strong measures such as increased social security need to be undertaken to reduce the risk. In addition to that, questions of housing, education, skill-building, nutritious food, clean environment all need answers preferably sooner than later." [14]. Finally, contrary to the public authorities, small private formal enterprises have implicitly recognized the positive dynamics of the informal traditional actors. These latter (like for example "Pompom" and "the Kabadiwala" ("Pompom" http:/ /www.pompom.in/; "the Kabadiwala" http:/ / www.thekabadiwala.com)) have begun to engage in the recycling sector, following directly the same dynamics by innovating with a mobile phone/online application to facilitate the sale of waste by its users to the company (which comes directly to their home to collect it and eventually resell it to the informal chain of recycling industries).

\section{3. "Surabaya Green and Clean" Programme: Encouraging Recycling}

With a GDP of 862 billion USD/year, Indonesia appears as an emerging economy. The city of Surabaya, located in East Java, is a strong economic and industrial part of the country. Surabaya lies on a $375 \mathrm{~km}^{2}$ area and hosts 2,975,358 inhabitants in 2016. If the whole urban area is to be included, the total population then rises up to 6.5 million people.

At the end of the 20th century, Surabaya was seen as a stifling and dirty city. Less than 20 years later, its avenues are green, 11 municipal parks can be found, among which the largest urban park in South-East Asia, and in 2012, Surabaya received the ASEAN Environmentally Sustainable City Award. Among these ecological improvements, municipal solid waste management (SWM) was completely revisited after a severe crisis that stroke public opinion.

Surabaya people produce on average $0.58 \mathrm{~kg}$ /year, which is 1782 tons throughout the city every day. The municipal service collects nearly $85 \%$ of it (1529 tons/day), whereas approximately $15 \%$ are recovered through the informal sector (232 tons/day). Municipal waste is mostly organic $(65 \%)$ and contains $28 \%$ of recyclable items. Until recently all collected waste was disposed in Keputih dumping site. However, in 2001, following complaints from neighbors, a judge ordered its immediate closure. It took nearly a month for municipal authorities to open a proper sanitary landfill. During more than three weeks, garbage accumulated in the streets, leading media to denounce a "waste flood". That episode strongly shook Surabaya's public opinion. During the following years, municipal authorities, local newspapers, private companies and residents' associations got strongly involved in the process of redesigning Surabaya's SWM policy.

The outcome of such a process was the "Surabaya Green and Clean" contest program which not only incentivized households to reduce their waste but which may also be seen as a way to include the existing informal recycling sector in the city's waste management system. Financed by private sponsors, it is a competition between neighborhoods, rewarding the most environmentally virtuous ones. For that purpose, not less than 420 "facilitators" and 28,000 "environmental cadres" were identified and trained throughout the city. In order to win the competition, local communities implemented various SWM tools. First, around 20,000 domestic composters were distributed to the population so that they would turn their kitchen wastes into compost for their plants and trees. In parallel, municipal authorities created 23 compost plants in order to recover the green waste from parks and streets. Then, Waste Banks (WB) emerged. These are community organizations, led by volunteer housewives, which buy recyclable items from households. The local administration gives them a small warehouse; a private sponsor provides minimal equipment (table, chairs, notebooks, weighing scale). To this day, around $420 \mathrm{WB}$ are active throughout the city. Each WB accepts from 15 to 50 different types of materials. The people who bring recyclable items are not paid at once; 
the amount they bring is recorded and they receive the money once a year. Most WB administrators sell the items they have gathered to specialized traders from the informal sector. If segregation and recycling through the WB remains dynamic, in recent years the composting habits (merely based on ethics and not on a financial gain) have neatly decreased.

\section{Discussion: Wastage (Dis-) Similitudes in Fast-Growing Asian Cities}

\subsection{A Similar Pre-Eminence of "End of Pipe" Solutions Which Appear to Be Non-Efficient}

Delhi, Hanoi or Surabaya are fast-growing Asian agglomerations which are facing similar constraints to manage their waste with a sprawling urbanization, a quick densification with high poverty levels, and weak municipal government capacities to handle such important issues. Like in many other developing cities, such limited capacities have led municipal authorities to make do with a minimal waste management service, limiting their efforts to reduce the sanitary risks in the city, by prioritizing waste collection and evacuation. As a result, Delhi, Hanoi, Surabaya have seen a multiplication of badly regulated and polluting dumps. At the same time, in the three cities there is the same growing recognition of the need to better control the socio-environmental impacts of waste flows as their improper management causes all types of pollution (air, soil, water) and constitutes a serious health treat (by facilitating the spread of epidemic diseases) [15].

In context of fast urbanization of the Asian region, this awareness is reminiscent of the industrialization of European cities in the last century, where an analogous increase of waste generated [16] had led to the emergence of the "hygienist" movement [17]. To a certain extent, one can observe a comparable "sanitary engineering" response [18] with the implementation of vast technical collection and disposal systems to transfer these risks to the periphery in a linear way. Such a preference for a technical "end-of-pipe" solution is understandable given the rapid urbanization and the growing waste volumes generated in cities. In addition, it does represent an upgraded strategy compared to open-air waste dumping. In the three cases observed in this article, this linear logic of evacuation remains the preponderant way to deal with municipal waste, even despite the lack of available space for new landfills in the three cities. Waste remains seen above all as a problem that should be swept away from the city.

\subsection{A Comparable Traditional but Informal Recycling Sector Which Emerges as an Alternative}

However, such a linear evacuation model, focused on sanitary landfilling, does not in any way solve the resources wastage issue. We should note here that the term "waste" is a relatively recent "invention" [16]. Human settlements, particularly urban agglomerations, have always been sources of solid and liquid refuse, and over a long period these residues were considered resources as they were naturally reused or transformed (agricultural spreading of sewage sludge, retrieval of wood, etc.). For the "dong nat" of Hanoi, the "Kabariwalla" of Delhi or the "pengepul" in Surabaya, which are at the bottom of a vast waste recycling pyramidal chain, waste materials is still considered as a valuable resource to be extensively exploited. These similitudes remain pregnant in Asian cities with craft villages in the periphery Hanoi specialized in one specific kind of material recovery or the very similar recycling semi-industrial areas found as well in Delhi. In the three cases as in many other developing cities in Asia, waste recycling appears to be strongly embedded within local practices which go against a simple linear eviction system. The reuse and recycling chain, which is only informal at its bottom (and then connects to formal traders and huge industries) does appear as an existing mechanism that reduces the resources wastage and contributes to a more circular economy.

Given the environmental crises and policy transformations, solid waste is once again perceived as resources to be exploited [16]. The linear economy for the sanitary disposal of urban waste appears more and more unsustainable and tends thus to be slowly replaced by new policies favoring the recovery of waste-resources. One sees the emergence of new forms of management, based on "environmental engineering" [18], which aim at decreasing the negative externalities of waste disposal. 
In the North, the emergence of new technologies that enable the provision of decentralized services at the neighborhood or building level (for example, autonomous waste water collection systems, small-scale waste methanation units, etc.) questions the emergence of a new "post-network" model for city planning [19]. In the global South, an increasing number of works focus on the importance of recycling in the dialectical waste/value relationship [20]. In Delhi, the modern replication by small formal private enterprises of the traditional Kabadiwala waste collection system is in itself a proof of its efficiency, which clearly demonstrates the essential role that the recycling agents can play. Like in many cities, "informal" channels of retrieval have been in existence for a long time, contributing to a circularity of flows that reduce environmental pressure, and may even be considered more efficient than formal "modernized" services" [21].

\subsection{A Complementarity Which Remain yet to Be Realised}

Recycling practices exist and are popular, as empirical evidence of strong waste economies demonstrates. Yet if planning documents slowly begin to acknowledge the existence of such systems, they remain to be formally integrated and properly regulated. Despite a growing recognition of the environmental value of informal recycling chains, the position toward these agents is still highly contrasted:

- The Hanoi case shows a classical situation of co-existence of a formal waste management service doing no valorization at all and neglecting informal recycling chains that strive to operate in a grey area, illegally for part of it. From this point, the public authorities can make a move towards or against the existing recycling local practices by favoring traditional actors or new large-scale private comers legally mandated. This "conflicting dichotomy" can be explained by the new value of waste: as incomes rise, and consumption and production patterns change together with the urbanization process, rejected material are increased in their volume and enriched in their quality, henceforth considered an economic good, and as such, characterized by a rivalry, the symptoms of which are the conflicts for its appropriation [22].

- The Delhi case is an example of clear public authorities' opposition to informal waste recycling agents, in order to favor a capital- and technology-intensive incineration scheme. At first sight, such equipment may seem appropriate for such a huge megalopolis as Delhi, because incinerators make it possible to considerably reduce the volume of waste to be buried and are largely used in western countries, especially in Europe. Nevertheless, several arguments do question its relevance. Which technical results may be expected, given the low calorific value of materials to be burnt? Is it reasonable to add gaseous emissions to the city's already critically polluted air at a time when international agencies recommend stopping burning waste in urban areas [23]? And what will the thousands informal workers will do for a living if such a huge equipment ends up sucking all dry waste?

- Academic debates about sustainability no longer consider it solely as an environmental concern, but also incorporate not only economic but also social dimensions specific to a given geographical context [24]. In other words, what appears to be sustainable in a region such as Europe may appear ambiguous in another place such as Asian cities, given a different socio-environmental context. In this regard, the Surabaya case shows that it is possible to create incentive mechanisms (like Waste Banks), relying on the value of waste, that include the informal sector into the public waste management system in order to foster recycling activities. Although quantitative results remain limited and informal traders manage to recover far more recyclable waste than Waste Banks do, a first inclusive step has been taken at the neighborhoods (kampungs) scale and a semi-decentralized waste management system thus rises, that aims at reducing the volumes of waste to be transported several miles away from the city center. 


\section{Conclusions: The Inevitable Integration of Recycling Sector}

The authorities' technological choices adapt with difficulty to the social complexity of contemporaneous urbanization processes. Almost always, informal recycling circuits appear as "archaic" devices to politicians in the global South, who aspire instead to "modernize" urban services.

More precisely, the attitude of municipal authorities towards the informal sector agents oscillates between ignorance, repression, collusion or integration [25]. In most cases, authorities ignore or repress informal sector agents: either they do not take them into account in the design of their management scheme, or they believe that these agents are harming the city's image and fight against them. Integration initiatives can be found in circumstances where waste-pickers are organized collectively, often to form cooperatives, as in Belo Horizonte (Brazil), Pune (India) or Bogotá (Colombia) [26].

Indeed, it is possible to make use of the existing local arrangements, in order to propose innovative solutions, which could improve the efficiency of the overall system. In the context of fast-growing Asian cities, the recognition of the importance of the informal recycling sector seems to be fundamental to achieve a better socio-environmental sustainability of any given infrastructural waste system. As they cover all different types of solid waste, collecting and recycling activities could improve the sustainability of the production/consumption/reuse cycle, thereby reducing the use of raw materials and save resources. Due to its considerable socio-environmental impacts, the waste recycling economy has real public interest potential. Formally recognizing these waste recycling workers is not only important for social justice, but also for environmental justice, making solid waste management more sustainable.

This would allow a progressive introduction of social and environmental norms in order to avoid the numerous current pitfalls of the sector, imperfect in many respects. Indeed, it goes without saying that the relegation of the sector to informality facilitates numerous abuses on the precarious labor conditions of the workers and entails several negative environmental externalities (e.g.,: releasing toxic liquids into the ground without prior treatment). Proper regulation could improve the sorting conditions, increase the volumes of recycled materials and support the urban economy by providing stable employment to a large number of workers. Furthermore, improved integration of the sector would guarantee jobs for sector workers. It is, therefore, necessary to look past the depressing image of a sector that, although far from perfect, tends to be open to abuse predominantly because it has been consigned to informality. Regulating and integrating recycling into the wider solid waste management sector would help ensure that social and environmental standards are progressively put in place.

A solution could lie in the regulation of an appropriate juxtaposition of this informal recycling sector and the vast, centralized, technical treatment systems in order to achieve a circularity of the flows at its best and allow at the same time positive socio-economics impacts. Yet, this turn would require more research in order to understand how these alternative systems can be properly articulated and adapted in practice to each specific context. If more and more emerging examples in the world tend to demonstrate that these inclusive choices are possible, critical analyses remain to be undertaken for allowing this paradigm shift to solve the waste crisis.

Acknowledgments: The authors would like to thank the French Development Agency (https://www.afd.fr/en), the (https:/ / en.ird.fr/the-ird) for funding these researches and Centre National de la Recherche Scientifique (http:/ / www.cnrs.fr/index.php) for supporting the writing of this article. We also thank the support of the Guest Editor of this Special Issue "Recycling In Emerging Economies: Practical Considerations for the Circular Economy in Fast-Growing Middle-income Cities and Countries", Anne Scheinberg.

Author Contributions: This paper in a joint collaboration. The authors conceived the research framework, realized the fieldwork and analyzed the data. The writing has been mostly done by Rémi de Bercegol with the help of Jérémie Cavé and Huyen Nguyen, in particular for presenting the empirical evidences.

Conflicts of Interest: The authors declare no conflict of interest. 


\section{References}

1. United Nations. World Population Prospects: The 2014 Revision; Department of Economic and Social Affairs Population Division: New York, NY, USA, 2014.

2. UN-Habitat. Urbanization and Development: Emerging Futures. 2016, 262p. Available online: https://unhabitat. org/books/world-cities-report/ (accessed on 9 December 2017).

3. UN-Habitat. Solid Waste Management in the World's Cities, London: United Nations Human Settlements Programme. 2010, 228p. Available online: https:/ / unhabitat.org/books/solid-waste-management-in-theworlds-cities-water-and-sanitation-in-the-worlds-cities-2010-2/ (accessed on 9 December 2017).

4. Rada, E.C.; Cioca, L. Optimizing the Methodology of Characterization of Municipal Solid Waste in EU under a Circular Economy Perspective. Energy Procedia 2017, 119, 72-85. [CrossRef]

5. Tecchio, P.; McAlister, C.; Mathieux, F.; Ardente, F. In search of standards to support circularity in product policies: A systematic approach. J. Clean. Prod. 2017, 168, 1533-1546. [CrossRef] [PubMed]

6. Furedy, C. Garbage: Exploring non-conventional options in Asian cities. Environ. Urban. 1992, 4, 42-61. [CrossRef]

7. Ministry of National Resources and Environment. Report on National State of Environment from 2011 to 2015; Ministry of National Resources and Environment: Hanoi, Vietnam, 2015.

8. Ministry of Construction. National Strategy for Integrated Management of Solid Waste up to 2025 and Vision towards 2050; Ministry of Construction: Delhi, India, 2009.

9. Viet, J.R. Preliminary Results of the Field Surveys; Surveys Organized by Nguyen Thai Huyen, Realized by Nguyen Tien Tam, Nguyen Truong Giang and students of the University of Architecture of Hanoi; University of Architecture of Hanoi: Hanoi, Vietnam, 2017.

10. Central Pollution Control Board. Status Report on Municipal Solid Waste Management; Ministry of Environment \& Forests: New Delhi, India, 2012. Available online: http://www.cpcb.nic.in/divisionsofheadoffice/pcp/ MSW_Report.pdf (accessed on 9 December 2017).

11. Amann, M.; Purohit, P.; Bhanarkar, A.D.; Bertok, I.; Borken-Kleefeld, J.; Cofala, J.; Heyes, C.; Kiesewetter, G.; Klimont, Z.; Liu, J.; et al. Managing future air quality in megacities: A case study for Delhi. Atmos. Environ. 2017, 161, 99-111. [CrossRef]

12. Chintan. Give Back Our Waste! What the Okhla Waste-to-Energy Plant Has Done to Local Wastepickers. 2012. Available online: http://www.chintan-india.org/documents/research_and_reports/chintan-reportgive-back-our-waste.pdf (accessed on 9 December 2017).

13. Chintan. Space for Waste Planning for the Informal Recycling Sector. 2003. Available online: http:/ / www.chintanindia.org/documents/research_and_reports/chintan_study_space_for_waste.pdf (accessed on 9 December 2017).

14. Arora, K. A Benchmark Year for Wastepickers, Posted by Alliance of Indian Wastepickers on Global Alliance of Waste Pickers' Website. 2016. Available online: http:/ /globalrec.org/2016/12/30/2016-a-benchmarkyear-for-wastepickers / (accessed on 9 December 2017).

15. UN-Habitat. The State of Asian Cities 2010/11. State of Cities-Regional Reports. 2010, 279p. Available online: https: / / unhabitat.org/books/the-state-of-asian-cities-201011/ (accessed on 9 December 2017).

16. Barles, S. History of waste management and the social and cultural representations of waste. Basic Environ. Hist. 2014, 4, 199-226.

17. Berdier, C.; Deleuil, J.M. The system 'city-waste' put into perspective. In City and Environment; Dorier-Apprill, E., Ed.; Sedes: Paris, France, 2006; pp. 453-466. (In French)

18. Barraqué, B. What is environmental engineering? In City and Environmental Engineering; Presses de l'ENPC: Paris, France, 1993; pp. 13-32. (In French)

19. Coutard, O.; Rutherford, J. (Eds.) Beyond the Networked City: Infrastructure Reconfigurations and Urban Change in the North and South; Routledge: London, UK, 2015.

20. Gidwani, V.; Rajyashree, N.R. The afterlives of "waste": Notes from India for a minor history of capitalist surplus. Antipode 2011, 43, 1625-1658. [CrossRef]

21. Wilson, D.C.; Velis, C.; Cheeseman, C. Role of informal sector recycling in waste management in developing countries. Habitat Int. 2006, 30, 797-808. [CrossRef]

22. Cavé, J. Who owns urban waste? Appropriation conflicts in emerging countries. Waste Manag. Res. 2014, 32, 813-821. [CrossRef] [PubMed] 
23. Unicef. Clear the Air for Children. 2016, 96p. Available online: https://www.unicef.org/publications / index_92957.html (accessed on 9 December 2017).

24. Rakodi, C.; Lloyd, T. (Eds.) Urban Livelihoods: A People-Centred Approach to Reducing Poverty; Earthscan Publications Ltd.: London, UK, 2002; 288p.

25. Medina, M. Waste Picker Cooperatives in Developing Countries. In Proceeding of the Membership-Based Organizations of the Poor; Wiego, Sewa: Ahmedabad, India, 2005; 22p.

26. Samson, M. Forging a New Conceptualization of "The Public" in Waste Management; Wiego Working Paper $\mathrm{N}^{\circ}$ 32; Women in Informal Employment: Globalizing and Organizing (WIEGO): Cambridge, MA, USA, 2015; 27p. Available online: http:/ /www.wiego.org/sites/wiego.org/files/publications/files/Samson-PublicWaste-Management-WIEGO-WP32.pdf (accessed on 9 December 2017).

2017 by the authors. Licensee MDPI, Basel, Switzerland. This article is an open access article distributed under the terms and conditions of the Creative Commons Attribution (CC BY) license (http:/ / creativecommons.org/licenses/by/4.0/). 